\title{
Intra- and interspecific nest parasitism of Common Moorhen (review of cases and new data)
}

\section{László HARASZTHY}

Received: March 19, 2018 -Revised: June 8, 2018 -Accepted: June 21, 2018

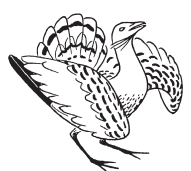

Haraszthy, L. 2018. Intra- and interspecific nest parasitism of Common Moorhen (review of cases and new data) - Ornis Hungarica 26(1): 95-101. DOI: 10.1515/orhu-2018-0007

Abstract Based on data available so far, it seems that Common Moorhens (Gallinula chloropus) rarely, but regularly lay one or more eggs in the nests of Common Little Bittern (Ixobrychus minutus). Three such incidents from Hungary are hereby added to the cases known to date. However, Common Moorhens do not only lay eggs in other species' nests, but also in the nests of conspecifics, while other species may also parasitise the nest of Common Moorhens. The present study summarises these aspects.

Keywords: intraspecific and interspecific nest parasitism, Common Moorhen, Common Little Bittern

Összefoglalás A vízityúk (Gallinula chloropus) az eddig rendelkezésre álló adatok alapján úgy tűnik, hogy ritkán, de rendszeresen rakja egy vagy több tojását törpegém (Ixobrychus minutus) fészkébe. Az eddigi esetszámot további három magyarországival sikerült kiegészíteni. A vízityúk azonban nem csak más fajok, hanem fajtársai fészkeibe is rakhat tojásokat, illetve más fajok az ö fészkeit parazitálhatják. Ezeket az eseteket foglalja öszsze a tanulmány.

Kulcsszavak: fajon belüli és fajok közötti fészekparazitizmus, vízityúk, törpegém

1174 Budapest, Damjanich utca 58., Hungary, e-mail: haraszthyl@gmail.com

\section{Introduction}

Giving birth to young or incubating eggs and eventually caring for the offspring till their independence are general forms of reproductive behaviour in mammals and birds. However, in other classes, mainly partial parental care is known. For birds, caring for their offspring may take weeks or months, and especially among mammals even longer periods of parental care are typical. This is a rather energy-consuming process with many hazardous components. It is common in the bird order Cuculiformes that certain species use other species to raise their offspring. Within the order, all 53 species in the subfamily Cuculinae follow this strategy (del Hoyo et al. 1997). However, this classic brood-parasitism is also typical for several other species, e.g. for the Black-headed Duck (Heteronetta atricapilla), but some examples where nestlings are raised by other species can also be found among weavers (Ploceidae). The number of truly brood-parasitic species is approximately 80 (Payne 1977).

In addition, numerous species are known to lay occasionally some or all of their eggs in the nests of other species (interspecific nest parasitism). Some females attempt to increase their breeding success with this strategy, but there can also be a number of other reasons for placing some or all of their eggs in other species' nests. 
It was only in the 1970s, when researchers turned their attention to another interesting phenomenon, i.e. nest parasitism between conspecifics (intraspecific nest parasitism). YomTov (1980) mentioned 53 species in which this fact has been proved. After this impressive publication, activities to better explore nest parasitism have increased, and hence the published lists of taxa in 1989 contained more than twice as many species (MacWrither 1989, Rohwer \& Freeman 1989).

The probability of intraspecific nest parasitism is higher if suitable nesting sites are insufficient, and if the breeding season is long. These factors increase the probability that nidifugous species lay their eggs in host nests (Yom-Tov 2001). A reason for this can be that nidifugous species have larger clutches than those of nidicolous species of the same size (Ar \& Yom-Tov 1978). These birds usually begin incubation after laying the last or the second last egg, and their incomplete clutches are unattended in the period preceding incubation. Furthermore, caring for an increased number of offspring, i.e. for their own and for the offspring of the nest parasites, does not require much additional effort on behalf of the hosts in the case of nidifugous species (Sorensen 1992).

It is widely known that if the nests of certain species are condensed in a small area, e.g. in large bird colonies, or in sites with a high nest density, or where available nesting sites are insufficient, the rate of intraspecific nest parasitism can be significantly higher (YomTov 1980).

Due to the increasing research in the field of breeding biology, the number of species known to employ intraspecific nest parasitism continuously grows. The updated list by Yom-Tov (2001) contains 234 species in 18 orders, in which multiple evidence has been found for intraspecific nest parasitism. The most numerous among them are the species belonging to the orders Anseriformes (74), Galliformes (32) and Chradriiformes (19). However, there are several species, in which the occurrence of intraspecific nest parasitism has been revealed since then, such as the Eurasian Thick-knee (Burchinus oedicnemus) or the Mediterranean Gull (Larus melanocephalus), and the Whiskered Tern (Chlidonias hybridus) (Haraszthy 2018 in print).

Significantly less information is available on interspecific nest parasitism. It may even happen that a parasitic species that has nidifugous chicks lays eggs in the nests of species whose nestlings are nidicolous. Many questions are unresolved in interspecific nest parasitism. It is still not known whether individual females parasitise always the same host species or if they vary them. Nor is it known what proportion of females within each parasitic species apply this strategy or how successful they are. Hötker (2000) concluded that in Pied Avocets (Recurvirostra avosetta) significantly more chicks hatch from the usual four-egg clutches than from parasitised clutches with an increased number of eggs.

Another interesting point about interspecific nest parasitism is that a species can be a parasite and a host at the same time. The Common Moorhen (Gallinula chloropus) is a good example. Moreover, it may lay its eggs in the nests of nidifugous as well as nidicolous species, while so far only nidifugous species are known to lay their eggs in the nests of this species.

The Common Moorhen is a widespread species, inhabiting three continents. The species is native in large parts of North, West and Southern Africa. It is also widespread all over Europe, except for most of Scandinavia. The breeding range extends east in Asia nearly to the 
Baikal region, and the species is resident in South and Southeast Asia to the western parts of the Indonesian archipelago (Taylor 1996).

The Common Moorhen is a considerably adaptable species, breeding in a variety of habitats. Originally, it inhabited both smaller and larger standing waters that had large reedbeds and at least patches of open water, but later it also occupied slowly flowing canals with reed belts. Today, Common Moorhens can be found at city ponds as well as in smaller or larger wetlands created by the most diverse industrial activities (Cempulik 1993). Nests were originally built on reed or reedmace, sometimes in small bushes in such vegetation, but almost always directly above water. Among those Common Moorhens breeding in cities, it is not uncommon to build the nest several metres high on trees (Engler 1983).

Originally, the Common Moorhen was a territorial species, but its adaptation to smaller wetlands resulted in partially abandoning this behaviour. Colonial breeding of several pairs is increasingly more common, and polyandry and polygyny also occur more and more often in this formerly primarily monogamous species, while there are also several records of interspecific brood parasitism (e.g. Gibbons 1986, Post \& Seals 2000, Forman 2003).

So far, relatively little attention has been paid to the breeding biology of the Common Moorhen. What is known best that intraspecific nest parasitism can be significant in populations with higher densities. However, egg pattern does not allow distinction of eggs from stranger females. Proving that two or more females lay eggs in an observed nest is only possible if several new eggs are laid in the nest on a single day, or if new eggs are laid in a nest several days after the clutch is complete. Proving the identity of eggs from stranger females is thus only possible in constantly monitored nests.

\section{Common Moorhen eggs in the nests of different species}

In several cases, Common Moorhens laid their eggs in the nests of the closely related Common Coot (Fulica atra) that shared the same habitat. However, the first observations of such incidents occurred in bird parks where the two species bred in large numbers in each others' immediate vicinity. In these English bird parks goose, duck and swan species are kept in captivity, in pairs or smaller groups. Each pair or group has a small pond surrounded by some lawn. The smaller ponds also have patches of reed or reedmace, offering ideal nesting sites to the wild Common Moorhens. Density is particularly high in such places, since the wildfowl fodder available in abundance is also favoured by Common Moorhens (Gibson 1986, Forman 2003).

Cases are also known when Common Moorhens laid an egg in a Grey Partridge (Perdix perdix) and in a Little Grebe (Tachybaptus ruficollis) nest (Engler 1983). In Great Britain, a Black-headed Gull (Larus ridibundus) successfully hatched two Common Moorhen eggs laid next to its own egg. The nestlings later joined a pair of Common Moorhens that were leading their own chicks (Jones 1988). Meniaia et al. (2014) found a Common Moorhen egg in a Ferruginous Duck (Aythya nyroca) nest during their research at Lake Tonga in Algeria. This nest also contained a White-headed Duck (Oxyura leucocephala) egg. The same researchers found 7 Common Moorhen eggs in an abandoned Purple Swamphen (Porphyrio porhyrio) nest, too. 
The author found three Common Moorhen eggs next to eight duck eggs in a Mallard (Anas platyrhynchos) nest at Dinnyés on 23 May 2004. In the above cases, with the exception of the Black-headed Gull, the Common Moorhen eggs were laid into the nests of nidifugous species. The egg laid in the Grey Partridge nest is of particular interest, as that species has a different habitat from that of the Common Moorhen.

In addition to the above observations made in Europe and North Africa, only one occasion, an egg of the closely related Common Gallinule (Gallinula galeata) was found in the nest of the North American Boat-tailed Grackle (Quiscalus major) that nests colonially in reedbeds, which is particularly interesting as this species is extremely far from the genus Gallinula in taxonomy, ecology, and especially in breeding behaviour (Post \& Seals 1989).

\section{Common Moorhen eggs in nests of Ixobrychus bitterns}

By 2010, only seven cases have been revealed when Common Moorhens laid their eggs in the nest of an Ixobrychus bittern species. Common Little Bittern (Ixobrychus minutus), which is also native in Hungary, was parasitised in only three of these cases (David et al. 2005, Pardo-Cervera et al. 2010, Samraoui et al. 2012), while in four instances the eggs were laid in Yellow Bittern (Ixobrychus sinensis) nests (Ueda 1993, Ueda \& Narui 2004). This is also interesting because Common Moorhens laid their conspicuously marked eggs in the nests of species that share the same habitat but have snow white clutches. The nestlings of Ixobrychus bitterns are nidicolous, fed by their parents in the nest.

In addition to the three cases published so far where Common Moorhens parasitised the nests of Common Little Bitterns, similar cases are known from Hungary that have not been published until recently or not at all, while one of them was published only in Hungarian and in a place where it could not become widely known.

\section{Description of the Hungarian cases}

1. - On 3 June 1962, Jenő Radetzky found a three-egg clutch of Common Little Bittern in Soponya, with a Common Moorhen egg in the nest (Solti 2012).

2. - On 10 June 1979, Rékási (1980) found Common Little Bittern nests under three Purple Heron nests in a colony of the latter species at Madaras, and one of them contained three typically patterned Common Moorhen eggs alongside three white Common Little Bittern eggs. Ten days later, this clutch had been robbed by a European Water Vole (Arvicola amphibius), while the other two nests that only contained eggs of Common Little Bittern were unharmed. The question arises whether the parasitised nest had been deserted by the Common Little Bittern which thus opened the way to nest robbery?

3. - On 29 May 2005, the author found a nest in the reed belt of the Hortobágyi-Halastó (Hortobágyi Fishponds) with five Common Little Bittern eggs and a Common Moorhen egg next to them. The nest was built on reed stems in the vicinity of a mixed heron colony with nests of Glossy Ibis (Plegadis falcinellus), Black-crowned Night-heron (Nycticorax 
nycticorax), Great White Egret (Ardea alba), Little Egret (Egretta garzetta), Squacco Heron (Ardeola ralloides), and Pygmy Cormorant (Microcarbo pygmeus).

From the above records it can be concluded that the first two event took place much earlier than the other cases published so far (David et al. 2005, Pardo-Cervera et al. 2010, Samraoui et al. 2012), and one of them is the first known case when more than one (3) Common Moorhen eggs were found in a Common Little Bittern nest.

The three records from Hungary indicate that in all likelihood Common Moorhens significantly more often lay one or more eggs in the nests of Common Little Bitterns or possibly of other species than so far supposed.

Numerous examples are known for intraspecific nest parasitism in Common Moorhens, as well as in other species. Even when nests are thoroughly monitored, it is not easy to reveal this phenomenon due to the great similarity of eggs. Based on the growing number of proven cases, numerous authors assume that intraspecific nest parasitism is significantly more frequent than previously supposed (Macwhirter 1989, Lyon 1993). It is widely accepted that a nest can be considered to be parasitised if two eggs are laid in it on the same day, or if a new egg or eggs are laid in the nest at least two days after the clutch became complete (Lyon 1993). In the last decades, research has shown that in the various Coot and Moorhen species intraspecific nest parasitism occurs frequently. In the American Coot (Fulica america$n a)$, Lyon (1993) found at least one egg from stranger females in $41 \%$ out of 417 nests. In Namibia, Jamiesoni et al. (2000) found stranger eggs in $43 \%$ of the nests of Red-knobbed Coot (Fulica cristata), and in 21-36\% of the nests of Lesser Moorhen (Gallinula angulata). Meniaia et al. (2014) found eggs from stranger females in 10 nests (7.6\%) among those discovered at Lake Tonga in Algeria.

On 9 June 1974, the author found 15 eggs and three hatchlings in a Common Moorhen nest built under a Purple Heron nest in the Kunkápolnási Marsh (Csukás Marsh), Hortobágy, Hungary. On 8 May 1977, László Vilmos Szabó found a 21-egg clutch of Common Moorhen in a nest built on european ash (Fraxinus excelsior) sprouts in the flooded Vajdalaposi Forest Hortobágy (based on his diary and photo).

Common Little Bitterns breed in reedbeds and nests are thus found during targeted research, therefore, parasitism on them by Common Moorhen is only underpinned by occasional records. However, based on the cases observed abroad and in Hungary, it can be assumed that Common Moorhens lay eggs in Common Little Bittern nests more often than previously supposed.

\section{Parasitised nests of Common Moorhen}

Common Moorhens do not only parasitise the nests of other species, but can also become victims of brood parasitism. Fredrickson (1971) found two Ruddy Duck (Oxyura jamaicensis) eggs in the nest of the closely related Common Gallinule in Iowa, USA. In Algeria, Meniaia et al. (2014) studied 60 and 71 Common Moorhen nests in 2011 and in 2012 respectively, and found an egg each from Ferruginous Duck, White-headed Duck and Purple Swamphen. 


\section{Recommendations}

The above data indicates that the breeding behaviour of the Common Moorhen is rather complex. There are several open questions to be answered to get closer to understanding this complex and interesting breeding system. Questions to clarify include what happens to the Common Moorhen eggs laid in the nests of other species? Will they reach maturity, and if so, does its likelihood depend on the parasitised species, or is it a matter of chance? Beyond these life history traits, there are some important evolutionary biology questions as well. Are the females more inclined to parasitism more successful than those that only lay eggs in their own nests? Whether females inclined to parasitism lay more eggs or not. Is the presence of parasitism in a female's life contextual or permanent?

There are some questions that can be answered by methods tested in other host-parasitic systems (e.g. Moskát et al. 2003, Hauber et al. 2006, Honza \& Moskát 2008). The white eggs of the Common Little Bittern and the spotted eggs of the Common Moorhen are so different from each other that deception of the host species can be ruled out. How do Common Little Bitterns react to Common Moorhen eggs? Do they desert the parasitised nest, remove the stranger egg, or perhaps ignore it?

To sum up, it is to be clarified whether these cases occur from time to time by mere accident, or we are witnessing a change in the species' breeding strategy that has evolutionary advantages?

\section{Acknowledgements}

I thank Tibor Csörgő, Miklós Bán and two anonymous referees for their constructive comments and suggestions, which greatly helped to improve the manuscript.

\section{References}

Ar, A. \& Yom-Tov, Y. 1978. The evolution of parental care in birds. - Evolution 32: 655-669. DOI: 10.1111/ j.1558-5646.1978.tb04610.x

Cempulik, P. 1993. Breeding ecology of the Moorhen Gallinula chloropus in Upper Silesia (Poland). - Acta Ornithologica 28: 75-89.

David, A., Vass, C. \& Coroiu, I. 2005. A new casse of interspecific brood parasitism in the Common Moorhen Gallinula chloropus. - Avocetta 29: 33-39.

del Hoyo, J., Elliot, A. \& Sargatal, J. (eds.) 1977. Hanbook of the Birds of the World, Vol. 4. Sandgrouse to Cuckoos. - Lynx Editions, Barcelona

Engler, H. 1983. Die Teichralle [Common Gallinule]. - Die Neue Brehm-Bücherei 536., A. Ziemsen Verlag, Wittenberg, Lutherstadt (in German)

Forman, D. 2003. Moorhen interspecific brood parasitism. - British Birds 96: 429-431.

Fredrickson, L. H. 1971. Common Gallinule breeding biology and development. - The Auk 88: 914-919. DOI: $10.2307 / 4083849$

Gibbons, D. V. 1986. Brood parasitism and cooperative nesting in the Moorhen, Gallinula chloropus. - Behavioral Ecology and Sociobiology 19: 221-232.

Haraszthy, L. 2018. Fészkek és tojások [Nest and eggs]. - Pro Vértes Nonprofit Zrt., Csákvár (in Hungarian)

Hauber, M. E., Moskát, Cs. \& Bán M. 2006. Experimental shift in hosts' acceptance threshold of inaccurate-mimic brood parasite eggs. - Biology Letters 2(2): 239-241. DOI: 10.1098/rsbl.2005.0438 
Honza, M. \& Moskát, Cs. 2008. Egg rejection behaviour in the Great Reed Warbler (Acrocephalus arundinaceus): the effect of egg type. - Journal of Ethology 26: 389-395. DOI: 10.1007/s10164-008-0093-0

Hötker, H. 2000. Conspecific nest parasitism in the Pied Avocet Recurvirostra avosetta. - Ibis 142: 280-288. DOI: 10.1111/j.1474-919X.2000.tb04867.x

Jamieson, I. G., McRaer, S. B., Simmons, R. E. \& Trewby, M. 2000. High rates of conspecific brood parasitism and egg rejection in Coots and Moorhens in ephemeral wetlands in Namibia. - The Auk 117(1): 250-255. DOI: $10.1642 / 0004-8038(2000) 117[0250: H R O C B P] 2.0 . C O ; 2$

Jones, G. 1988. Moorhen and Black-headed Gull apparently laying in same nest. - British Birds 81: 642-643.

Lyon, B. E. 1993. Conspecific brood parasitism as a flexible reproductive tactic in American Coots. - Animal Behaviour 46: 991-928. DOI: 10.1006/anbe.1993.1273

MacWhirter, R. B. 1989. On the rarity of intraspecific brood parasitism. - Condor 91: 485-492. DOI: $10.2307 / 1368333$

Meniaia, Z., Samraoui, F., Alfarhan, A. H. \& Samraoui, B. 2014. Nest-site selection, breeding success and brood parasitism in the Common Moorhen Gallinula chloropus in Algeria. - Zoology and Ecology 24(4): 305-313. DOI: $10.1080 / 21658005.2014 .959281$

Moskát, Cs., Karcza, Zs. \& Csörgö, T. 2003. Egg rejection in European Blackbirds (Turdus merula): the effect of mimicry. - Ornis Fennica 80: 86-91.

Pardo-Cervera, F., Sørensen, I. H., Jensen-Ruiz, X. \& Sanchez-Alonso, C. 2010. Breeding biology of the Little Bittern Ixobrychus minutus in the Ebro delta (NE Spain). - Ardeola 57(2): 407-416. DOI: $10.1080 / 00063657.2012 .733335$

Payne, R. B. 1977. The ecology of brood parasitism in birds. - Annual Review of Ecology and Systematics 8: 1-28. DOI: 10.1146/annurev.es.08.110177.000245

Post, W. \& Seals, C. A. 1989. Common Moorhen parasitizes a Boat-tailed Grackle nest. - The Wilson Bulletin 101: 508-509.

Post, W. \& Seals, C. A. 2000. Breeding biology of the Common Moorhen in an impounded cattail marsh. - Journal of Field Ornithology 71: 437-442. DOI: 10.1648/0273-8570-71.3.437

Rékási, J. 1980. Madártani megfigyelések a madarasi nádasban fészkelő gém fajokon [Ornithological observations on the heron species breeding in the reedbed at Madaras]. - Állattani Közlemények 67: 125. (in Hungarian with English Summary)

Rohwer, F. C. \& Freeman, S. 1989. The distribution of inraspecific nest parasitism in birds. - Canadian Journal of Zoology 67: 239-253. DOI: 10.1139/z89-035

Samraoui, F., Nedjah, R. Boucheker, A., Alfarhan,A. H. \& Samraoui, B. 2012. Breeding ecology of the Little Bittern Ixobrychus minutus in Northeast Algeria. - Bird Study 59: 496-503. DOI: 10.1080/00063657.2012.733335

Solti, B. 2012. Radetzky Jenő tojásgyüjteményének katalógusa [The catalogue of the Jenő Radetzky oological collection]. - Folia Historico Naturalia Musei Matraensis 36: 123-138. (in Hungarian)

Sorenson, M. D. 1992. Comment: Why is conspecific nest parasitism more frequent in waterfowl than in other birds? - Canadian Journal of Zoology 70: 1856-1858. DOI: 10.1139/z92-253

Taylor, B. T. 1996. Common Moorhen. - In: del Hoyo, J., Elliott, A. \& Sargatal, J. (eds.) Handbook of the Birds of the World, Vol. 3. Hoatzin and Auks. - Lynx Edition, Barcelona, pp. 200-201.

Ueda, K. 1993. A case of inter-specific brood parasitism in the Moorhen Gallinula chloropus. - Strix 12: 224-226.

Ueda, K. \& Narui, Y. 2004. A new breeding tactic of the Common Moorhen: interspecific

brood parasitism of Bittern nests. - Ornithological Science 3: 163-166. DOI: 10.2326/osj.3.163

Yom-Tov, Y. 1980. Intraspecific nest parasitism in Birds. - Biological Reviews 55: 93-108. DOI: 10.1111/j.1469185X.1980.tb00689.X

Yom-Tov, Y. 2001. An updated list and some comments on the occurrence of intraspecific nest parasitism in birds. - Ibis 143: 133-143. DOI: 10.1111/j.1474-919X.2001.tb04177.x 